\title{
Tingkat Pengetahuan Berhubungan dengan Sikap Ibu dalam Toilet Training pada Toddler
}

\author{
Chori Elsera ${ }^{1}$ \\ 1STIKES Muhammadiyah Klaten \\ Jalan Jombor Indah, Buntalan, Klaten Tengah, Kabupaten Klaten, Jawa Tengah \\ Email: chorielsera@gmail.com
}

\begin{abstract}
Abstrak
Jumlah balita di Indonesia diperkirakan mencapai 30\% dari 250 juta jiwa penduduk Indonesia. Balita yang mengalami kesulitan dalam mengontrol BAB dan BAK (ngompol) di usia sampai prasekolah mencapai 75 juta anak. Salah satu faktor yang mempengaruhi toilet training pada balita adalah pengetahuan ibu tentang toilet training. Kurang pengeathuan ibu dan keluarga tentang toilet training dapat menghambat perkembangan anak dalam mengontrol pola BAK dan BAB. Tujuan penelitian untuk mengetahui hubungan tingkat pengetahuan dengan sikap dalam toilet training pada anak usia toddler di Desa Glodogan Kecamatan Klaten Selatan. Penelitian deskriptif kuantitatif dengan pendekatan cross sectional. Subyek penelitian adalah ibu yang mempunyai anak usia toddler di Desa Glodogan dengan jumlah populasi sebanyak 204 orang sedangkan sampel penelitian ini sebanyak 41 responden dengan teknik purposive sampling. Penelitian dilaksanakan pada 28 Juli-2 Agustus 2012 di desa Glodogan Kecamatan Klaten Selatan. Instrumen penelitian berupa kuesioner. Pengolahan data menggunakan analisis bivariat dengan chi square. Hasil yang diperoleh dari penelitian ini adalah tingkat pengetahuan responden baik. Sikap responden sebagian besar mendukung toilet training. Ada hubungan antara tingkat pengetahuan dengan sikap ibu dalam toilet training pada anak usia toddler di Desa Glodogan Kecamatan Klaten Selatan. Kesimpulan ada hubungan antara tingkat pengetahuan dengan sikap ibu dalam toilet training pada anak usia toddler di Desa Glodogan Kecamatan Klaten Selatan.
\end{abstract}

Kata Kunci: pengetahuan, sikap, toilet training

\section{Level of Knowledge Related to Attitude of Monther in Toddler Toilet Training}

\begin{abstract}
The number of children under five in Indonesia is estimated to reach $30 \%$ of the 250 million population of Indonesia. Toddlers who have difficulty in bowel and bladder control (wetting) at preschool age to reach 75 million children. One of the factors that affect toilet training in children under five is mother knowledge about toilet training. Less pengeathuan mothers and families about toilet training can hinder a child's development in the control of bladder and bowel patterns. The aim of research to know the correlation between knowledge with attitude in toilet training in children ages toddler in the village Glodogan Southern District of Klaten. Descriptive quantitative research with cross sectional approach. Subjects were mothers who have toddler children in the village Glodogan with a total population of 204 people while the study sample as many as 41 respondents using purposive sampling technique. The research was conducted on 28 July-2 August 2012 in the village Glodogan Southern District of Klaten. The research instrument was a questionnaire. Processing data using bivariate analysis using chi square. The results obtained from this study is a good level of knowledge. The attitude of most of the respondents supporting toilet training. There is a relationship between knowledge with attitude mother in toilet training in children ages toddler in the village Glodogan Southern District of Klaten. Conclusion no relationship between the level of knowledge of the attitude of the mother in toilet training in children ages toddler in the village Glodogan Southern District of Klaten.
\end{abstract}

Keywords: knowledge, attitude, toilet training

Info Artikel:

Artikel dikirim pada 21 Januari 2016

Artikel diterima pada 24 Februari 2016

DOI : http://dx.doi.org/10.21927/jnki.2016.4(1).35-38 


\section{PENDAHULUAN}

Periode penting dalam tumbuh kembang anak adalah masa balita. Pada masa ini pertumbuhan dasar yang akan mempengaruhi dan menentukan perkembangan anak selanjutnya. Pada masa balita ini perkembangan kemampuan berbahasa, kreativitas, kesadaran sosial, emosional, dan intelegensia berjalan sangat cepat dan merupakan landasan perkembangan berikutnya(1).

Kebiasaan mengompol pada anak di bawah usia 2 tahun merupakan hal yang wajar, bahkan ada beberapa anak yang masih mengompol pada usia 4-5 tahun. Beberapa penelitian disebutkan bahwa kira-kira setengah dari anak umur 3 tahun masih mengompol. Bahkan beberapa ahli menganggap bahwa anak umur 6 tahun masih mengompol itu wajar, walaupun itu hanya dilakukan oleh sekitar $12 \%$ anak umur 6 tahun. Kendati demikian hasil ini tidak dapat dijadikan argumen bagi orang tua untuk menunda mengajarkan anak belajar bagaimana cara yang benar untuk buang air kecil dan buang air besar dan di tempat yang tepat. Hal ini penting saat anak akan masuk bangku sekolah(2). Bila anak diajarkan ketika usia lebih dari 3 tahun dikhawatirkan agak susah mengubah pola yang sudah menjadi perilaku.

Dampak yang paling umum dalam kegagalan toilet training seperti adanya perlakuan atau aturan yang ketat dari orang tua kepada anaknya yang dapat mengganggu kepribadian anak yang cenderung bersifat retentive dimana anak cenderung bersikap keras kepala bahkan kikir. Hal ini dapat terjadi apabila orang tua sering memarahi anak pada saat buang air besar atau buang air kecil atau melarang anak untuk buang air besar atau buang air kecil saat bepergian karena sukar mencari toilet. Bila orang tua santai dalam memberikan aturan dalam toilet training maka anak akan dapat mengalami kepribadian eksprensif dimana anak lebih tega, cenderung ceroboh, suka membuat gara-gara, emosional dan seenaknya dalam melakukan kegiatan sehari-hari(3).

Menurut Wong, sejalan anak mampu berjalan maka anak semakin mampu pula mengontrol rasa ingin berkemih dan buang air besar(4). Kemampuan untuk mengontrol rasa ingin defekasi biasanya lebih dahulu tercapai dibandingkan kemampuan dalam mengontrol rasa ingin berkemih. Sensasi untuk defekasi lebih besar dirasakan oleh anak dan kemampuan untuk mengkomunikasikannya lebih dahulu dicapai anak.

Melakukan pelatihan buang air kecil dan besar pada anak membutuhkan persiapan baik secara fisik maupun secara intelektual melalui persiapan tersebut diharapkan anak mampu mengontrol buang air besar dan air kecil secara mandiri. Pada toilet training selain melatih batita mengontrol buang air kecil dan besar juga dapat bermanfaat dalam pendidikan seks. Sebab saat batita melakukan kegiatan tersebut disitu batita akan mempelajari anatomi tubuhnya sendiri serta fungsinya. Dalam proses toilet training diharapkan terjadi pengaturan impuls atau rangsangan dan insthink batita dalam melakukan buang air besar dan air kecil. Perlu diketahui bahwa buang air besar merupakan suatu alat pemuasan untuk melepaskan ketegangan dengan latihan ini batita diharapkan dapat melakukan usaha penundaan pemuasan(3).

Penelitian ini bertujuan untuk mengetahui hubungan tingkat pengetahuan dan sikap ibu dalam melaksanakan toilet training pada anak usia toddler di Desa Glodogan, Kecamatan Klaten Selatan, Kabupaten Klaten.

\section{BAHAN DAN METODE}

Penelitian ini merupakan deskriptif kuantitatif, desain korelasional, menggunakan rancangan cross sectional. Sampel dalam penelitian ini adalah ibu yang memiliki anak usia toddler (1-3 tahun) di desa Glodogan Klaten Selatan. Jumlah sampel sebesar 41 responden dengan teknik pengambilan sampel purposive sampling. Uji hipotesis dengan menggunakan chi-square. Pengumpulan data dilakukan secara wawancara dengan kuesioner. Uji validitas dan reliabilitas di lakukan di desa Canan kecamatan Wedi pada 20 orang responden dengan hasil semua item pertanyaan yang tersedia dinyatakan valid dengan nilai $r$ hitung $0,857>r$ tabel $(0,7)$ dan pertanyaan pada kuesioner ini memiliki nilai $\alpha=0,916$ sehingga dinyatakan reliabel.

Adapun kriteria inklusi pada penelitian ini antara lain: ibu tinggal bersama anak, ibu berusia 20-35 tahun, pendidikan terakhir ibu minimal sederajat SMP, ibu mempunyai anak maksimal 2orang. Sedangkan kriteria eksklusi: ibu memiliki anak difable, anak dengan stoma, ibu berpendidikan keperawatan serta tidak memiliki fasilitas BAB (WC) di rumah.

\section{HASIL DAN BAHASAN}

\section{Karakteristik Responden}

Distribusi frekuensi karakteristik responden dibagi atas umur, jumlah anak, dan pendidikan disajikan dalam Tabel 1.

Berdasarkan Tabel 1 gambaran karakteristik responden dengan kelompok umur 20-27 tahun yakni sebanyak 34 responden (82\%). Sebagian besar responden mempunyai satu anak yaitu sebesar 
Tabel 1. Distribusi Karakteristik Responde Tingkat Pengetahuan dengan Sikap lbu dalam Toilet Training pada Anak Usia Toddler di Desa Glodogan Kecamatan Klaten Selatan

\begin{tabular}{lcc}
\hline \multirow{2}{*}{ Karakteristik Responden } & \multicolumn{2}{c}{ Total } \\
\cline { 2 - 3 } & $\mathbf{f}$ & $\%$ \\
\hline Umur & 34 & 82,9 \\
$20-27$ tahun & 7 & 17,1 \\
$28-35$ tahun & & \\
Jumlah Anak & 37 & 90,2 \\
1 & 4 & 9,8 \\
2 & & \\
Pendidikan & 7 & 17,1 \\
SMP & 29 & 70,8 \\
SMA & 5 & 12,1 \\
$\quad$ Perguruan Tinggi & 41 & 100 \\
Jumlah &
\end{tabular}

$90,2 \%$. Sebanyak 29 responden $(70,8 \%)$ responden berpendidikan lulus SMA sederajat. Dua puluh delapan responden $(68,3 \%)$ berpengetahuan baik tentang toilet training. Sebagian besar responden bersikap mendukung dalam toilet training sebesar 35 responden $(85,4 \%)$.

\section{Analisis Bivariat}

Hasil analisis bivariat hubungan antara tingkat pengetahuan dengan sikap ibu dalam toilet training pada anak usia toddler di Desa Glodogan Kecamatan Klaten Selatan disajikan dalam Tabel 2.

Berdasarkan Tabel 2 hasil analisis bivariat diperoleh nilai $p$-value $=0,00$ yang berarti $p<0,05$ maka secara statistik Ho ditolak dan Ha diterima berarti terdapat hubungan yang bermakna antara tingkat pengetahuan dengan sikap ibu dalam toilet training pada anak usia toddler di Desa Glodogan Kecamatan Klaten Selatan.

Berdasarkan hasil penelitian diketahui bahwa sebagian besar responden berumur 20-27 tahun yakni sebanyak 34 orang $(82,9 \%)$. Pada rentang umur ini ibu masih produktif dan cepat tanggap terhadap perkembangan anak sehingga pengetahuan ibu baik dan sikap ibu dalam toilet training akan lebih mendukung. Berdasarkan teori Notoatmodjo, salah satu faktor yang mempengaruhi pengetahuan adalah usia(5). Semakin tua semakin bijaksana, semakin banyak informasi yang dijumpai dan semakin banyak hal yang dikerjakan sehingga menambah pengetahuannya.

Hasil penelitian responden berdasarkan jumlah anak di Desa Glodogan yang paling banyak adalah responden dengan jumlah anak 1 orang yakni sebanyak 37 orang $(90,2 \%)$. Berdasarkan penelitian jumlah anak tidak berpengaruh kuat pada pengetahuan dan sikap ibu karena pengetahuan tidak hanya didapat dengan pengalaman pribadi yaitu memiliki anak lebih dari satu tetapi juga dari cerita pengalaman orang lain.

Berdasarkan penelitian pada responden tingkat pendidikan di Desa Glodogan yang paling banyak adalah responden dengan pendidikan SMA yakni sebanyak 29 orang $(70,8 \%)$. Sekarang lebih banyak orang yang menempuh pendidikan sampai SMA daripada SD, SMP maupun Perguruan Tinggi. Salah satu faktor penyebabnya adalah masalah sosial ekonomi, serta kemauan untuk meraih pendidikan yang lebih tinggi. Menurut Notoatmodjo, tingkat pengetahuan seseorang terhadap suatu objek sangat ditentukan oleh tingkat pendidikan(5).

Hasil penelitian menunjukkan bahwa dari 41 responden sebagian besar memiliki tingkat pengetahuan yang baik tentang toilet training yaitu sejumlah $28(68,3 \%)$. Hal ini sesuai dengan teori yang diungkapkan Notoatmodjo, bahwa semakin tinggi pendidikan seseorang, maka akan mudah menerima hal-hal baru dan mudah menyesuaikan dengan hal-hal yang baru tersebut(6). Semakin tinggi pendidikan seseorang maka pengetahuannya semakin luas, semakin baik dan mempermudah orang dalam menerima informasi.

Berdasarkan hasil penelitian, sikap responden terhadap toilet training sebagian besar mendukung yaitu sebanyak 35 responden $(85,4 \%)$. Sikap adalah suatu bentuk evaluasi atau reaksi perasaan. Sikap

Tabel 2. Hubungan Tingkat Pengetahuan dengan Sikap Ibu dalam Toilet Training pada Anak Usia Toddler di Desa Glodogan Kecamatan Klaten Selatan

\begin{tabular}{|c|c|c|c|c|c|c|c|}
\hline \multirow{3}{*}{ Variabel } & \multicolumn{4}{|c|}{ Sikap } & & & \multirow{3}{*}{$p$-value } \\
\hline & \multicolumn{2}{|c|}{ Mendukung } & \multicolumn{2}{|c|}{$\begin{array}{c}\text { Kurang } \\
\text { Mendukung }\end{array}$} & \multicolumn{2}{|c|}{ Total } & \\
\hline & $n$ & $\%$ & $n$ & $\%$ & $\mathbf{n}$ & $\%$ & \\
\hline \multicolumn{8}{|l|}{ Pengetahuan } \\
\hline Baik & 28 & 68,3 & 0 & 0 & 28 & 68,3 & \\
\hline Cukup & 7 & 17 & 6 & 14,6 & 13 & 31,7 & 0,00 \\
\hline Kurang & 0 & 0 & 0 & 0 & 0 & 0 & \\
\hline Total & 35 & 85,3 & 6 & 14,6 & 41 & 100 & \\
\hline
\end{tabular}


seseorang terhadap satu obyek adalah perasaan mendukung atau memihak maupun perasaan tidak mendukung atau tidak memihak pada obyek tersebut secara lebih spesifik sebagai derajat efek positif atau negatif(7). Sikap responden dalam penelitian ini sebagian mendukung karena beberapa faktor, diantaranya yaitu usia yang masih produktif serta jumlah anak yang tidak terlalu banyak sehingga ibu lebih tanggap mengenai perkembangan anak.

Hasil analisis bivariat hubungan dua variabel yaitu tingkat pengetahuan dengan sikap ibu dalam toilet training pada anak usia toddler di Desa Glodogan menunjukkan adanya hubungan antara tingkat pengetahuan dengan sikap ibu dalam toilet training dengan nilai $p=0,000$ yang berarti $(0,000<0,05)$. Jadi dalam hal ini hipotesis kerja diterima, yang berarti semakin baik pengetahuan maka sikap akan semakin mendukung dalam toilet training. Hal ini sesuai dengan penelitian yang dilakukan Astika yaitu sebagian besar responden memiliki pengetahuan yang baik tentang toilet training anak sebanyak 195 responden (87\%) dan sikap yang mendukung sebanyak 166 responden $(74,1 \%)(8)$.

Berdasarkan penelitian yang dilakukan oleh Mota, sekitar 10,2 ibu yang mendapat petunjuk medis tentang toilet training, 64,7\% ibu menggunakan intuisi tanpa mendapat petunjuk dari siapapun untuk toilet training anak dan sisanya ibu mendapat beberapa petunjuk dari ibu mereka tentang toilet training(9). Ibu mulai toilet training dan tidak memakaikan popok sekali pakai pada anak berdasarkan umur anak sebanyak $54,2 \%$ dan berdasarkan keinginan anak sebanyak $20,5 \%$. Ibu yang mengalami kegagalan usaha sebelumnya dalam toilet training anak sebanyak $41 \%$. Hal ini menunjukkan bahwa ibu yang memiliki pengetahuan yang cukup tentang toilet training akan mempengaruhi kesuksesan ibu dalam usaha toilet training pada anak.

Berdasarkan penelitian yang dilakukan oleh Irmaatus Sholihah, dengan uji chi-square didapatkan hasil penelitian Gambaran pengetahuan ibu tentang kesiapan toilet training pada anak usia 18-24 bulan $70 \%$ cukup, kesiapan fisik toilet training $60 \%$ cukup, kesiapan psikologis toilet training $55 \%$ cukup(10). Hal ini menunjukkan adanya hubungan antara pengetahuan tentang toilet training dengan kesiapan fisik maupun psikologis toilet training sehingga berpengaruh pula pada sikap dalam toilet training karena kesiapan psikologis merupakan salah satu faktor yang mempengaruhi toilet training yaitu faktor emosional.

\section{SIMPULAN DAN SARAN}

Terdapat hubungan yang bermakna antara pengetahuan ibu terhadap sikap ibu dalam toilet training pada anak usia toddler di Desa Glodogan Kecamatan Klaten Selatan Kabupaten Klaten.

Bagi tenaga kesehatan agar meningkatkan penyuluhan kepada ibu yang mempunyai anak balita tentang pentingnya toilet training pada anak sehingga ibu dapat termotivasi untuk melakukan toilet training pada anak. Bagi masyarakat agar mencari informasi khususnya tentang toilet training serta menerapkannya dalam kehidupan sehari-hari sehingga anak akan terbiasa buang air di toilet. Bagi profesi Perawat lebih memahami tentang toilet training pada anak dan dapat menerapkan saat memberikan asuhan keperawatan pada anak.

\section{RUJUKAN}

1. Soetjiningsih. Tumbuh Kembang Anak. Jakarta: EGC; 2002.

2. Mufattahhah S. Training Untuk Batita [Internet]. 2007 [cited 2012 Feb 2]. Available from: http:// cenitcenit.multiply.com/journal.

3. Hidayat A. Pengantar Ilmu Keperawatan Anak 1. 4th ed. Jakarta: Salemba Medika; 2008.

4. Whaley, Wong's. Nursing Care of Infants and Children. USA: Mosby-Year Book; 2002.

5. Notoatmodjo S. Promosi Kesehatan Teori dan Aplikasi. Jakarta: Rineka Cipta; 2007.

6. Notoatmodjo S. IImu Kesehatan Masyarakat. Jakarta: Rineka Cipta; 2003.

7. Azwar S. Sikap Manusia: Teori dan Pengukurannya. Yogyakarta: Pustaka Pelajar; 2010.

8. Astika A. Hubungan Antara Tingkat Pengetahuan dan Sikap Ibu dengan Perilaku Ibu Dalam Melatih Toileting Anak Usia Toddler di Wilayah Puskesmas Banyudono I Boyolali. Universitas Gadjah Mada; 2009.

9. Mota DM, Barros AJD. Toilet training: Methods, Parental Expectation and Associated Dysfunction. J Pediatr (Rio J). 2008;84(1):9-17.

10. Irmaatus S. Gambaran Pengetahuan Ibu tentang kesiapan toilet training pada anak usia 18-24 bulan di dusun Pandantoyo Kecamatan Ngancar Kabupaten Kediri. Universitas Gadjah Mada; 2009. 